\title{
Evaluation of Practical Courses from the Perspective of Students of Faculty of Tourism and Hospitality in the University of Jordan, Aqaba Branch
}

\author{
Rami Muneer Mahmoud \\ Food and Beverage Management Department, Faculty of Tourism and Hotels \\ The University of Jordan
}

Received: February 26, 2014

Accepted: March 19, 2014 Published: April 1, 2014

doi:10.5296/jmr.v6i2.5189

URL: http://dx.doi.org/10.5296/jmr.v6i2.5189

\begin{abstract}
Practical programs are considered essential in universities and institutions specialized in tourism and hospitality. This study aimed at evaluating the practical program from the perspective of students of Faculty of Tourism and Hospitality, the University of Jordan. The study focused on four subscales to recognize the variations in program efficiency degree in respect with supervision, evaluation, possibilities and organization. In this study, (80) students, who have finished their training course, have participated in answering a questionnaire consisted of (27) paragraphs. The Study findings showed that all pivots have received a high degree of efficiency. It has been shown that it is necessary for the Faculty of Tourism and Hospitality in the University of Jordan to ensure that the trainer is using modern teaching methods and techniques. Also, the Faculty of Tourism and Hospitality in University of Jordan should provide equipped laboratories for several practical applications with adequate space that suits the students. Also, it should provide education and explanation methods in the Faculty (video, books on Tourism and Hospitality, and tapes.)
\end{abstract}

Keywords: Practical courses, Evaluation, Supervision, Jordan, Possibilities 


\section{Introduction}

In terms of importance and tangible benefit of practical course for students and their host universities and institutions which try to combine between the theoretical part and practical parts of their academic calendar. Training is considered as a strategic option for any education authority that looks for preparing human cadres which are able to meet the requirements of business, to keep abreast with development, and also to promote their property image which enable them to compete regionally and internationally. Training is considered as the actual foundation period for the students to be involved in scope of work, and it is a significant period where students must utilize it as much as necessary before being officially involved in the actual scope of work, whether through acquiring the needed experience for the beginning and knowledge of business situation, or through applying the theoretical information they gained during their studying period. The mission of the University of Jordan- Faculty of tourism and hospitality is to apply the theoretical information in practice, not only the application, but also the knowledge of such information and applications acquired closely and actually.

Training is important as students recognize the nature of work whether it's in hotels, restaurants, or other tourism services. It will enable them to understand the work's transactions, its management procedures, and how to deal with them. Training will provide them with a lot of knowledge in the field of laws and regulations which govern the actual scope of work. Moreover, students who are involved in training will be able to recognize many problems surrounding the actual scope of work, which will give them the chance to utilize their theoretical outcome in solving, overcoming, and finding proper solutions for such problems. The significance of training lies not only to the strictly application of such theoretical information acquired, but also it is a field and a fertile ground to develop the creativity and intellectual skills of students in order to achieve new creative and innovative methods.

\section{Previous research}

Due to the significance the practical training course has in the preparation of future competent students, several studies have been conducted on such subject (practical training) in different Arab and foreign countries, but most studies have been concentrated on different sections of sciences which have no relationship with tourism and hospitality education. Considering practical training as an interface between practical and theoretical sides, the researcher discusses the studies which are related to the practical training in general, and which are able to be compared in the field of tourism and hospitality.

One of the Arabic studies which have been conducted on the field of practical training courses is that of Al-Haliq, Taheeneh, and salameh, (2006) who conducted a study entitled "Evaluating the field-training program for physical education students at the Hashemite University”. The results of their study revealed high degree of effectiveness for supervision, evaluation, and educational competencies, and a moderate degree of effectiveness for organization and facilities. Abu Namira (2005) has conducted a study aiming at evaluating the practical education program in the faculties of educational sciences in the private 
universities of Jordan from the perspective of teaching students. The study of Abdul-Rahman, Abul-Tayeb and Al-Kilani (2004) which has been conducted on a sample of 24 male and female trainees of practical training students who have completed (80) credit hours in the Hashemite University, aimed at recognizing the effect of practical training on the teaching skill improvement of the students of the Faculty of Physical Education and Sports Science. The results have indicated that the capabilities of trainees can be affected by a number of external influences which can be the factor of having differences in the practical course (1) rather than the practical course (2).

Mesmar, and Al-khawaja (1996) have conducted a study aiming at recognizing the attitudes of students and graduates toward the practical application course in the faculties of physical education in Jordan. The results showed that the attitudes of students and graduates were negative toward the course coordination, supervision, the schools for practical application, and evaluation. Also, the results showed that there are no significant variations, attributable to gender and faculty variables, between the students who are still studying, and the graduates in connection with the attitudes toward the practical application course. In addition, Fahmi (2007) assessed the opinions of Members of Education Faculty and students of Education Faculty in regard to the most significant problems and difficulties they face during practical training. Talafha (2003) has conduct a study aiming at evaluating the program of practical education at the Faculty of Teachers in Tabuk, in order to recognize the strengths and weaknesses of such program from the perspective of the trained student, supervisor, and headmaster.

For the foreign studies conducted on the field of practical training program evaluation such as (Mayaka\& Akama, 2007, Ritchie \& Pollock, 1990, Wood, 2000). Mayaka and Akama (2007) have conducted a study entitled "Systems Approach to Tourism Training and Education: The Kenyan Case Study". The study concluded that Kenya provides a good case study for the deficiencies of touristic training which distinguishes many countries in Africa and other touristic directions all over the world. In addition, this study shows that Kenya, as any other third world country, lacks touristic training as a well-coordinated strategy, particularly at the supervision and management level. It also defines the current deficiencies of Kenya in education, training and tourism, and it provides frameworks which can be applied to develop a well-coordinated national strategy for touristic training and commencing education.

Both Ritchie and Pollock (Ritchie \& Pollock, 1990) have conducted a study on an integral strategy of education and touristic training. The study showed that tourism requires a comprehensive framework through which educational and training programs can be designed and provided more efficiently. Also, it requires a formulation of an integral strategy underlying the planning and development of education and touristic training system. The purpose of such integration is to ensure a higher degree of correlation between the different levels of the entire education system in order to provide a clearly defined action plan along with the alternative functional tracks hereinafter. Then, the preliminary results of the strategy are revised for the development of education infrastructure. 
The study conducted by. Baker, Cattet and Riley (Baker, Cattet \& Riley 1995) was Describes a research study into the use of practical food and beverage facilities - the teaching restaurant and production kitchen - in undergraduate degree courses in hospitality management. Discusses the priority placed on the possession and use of these facilities and their relevance. Yiu \& Law ( Yiu \& Law 2012) have conducted the role and value of the internship in hospitality education and Its benefits and drawbacks are discussed from the perspectives of the three stakeholders, and an overall assessment was discussed.

Al-Salem (2009) pointed out to the importance of practical courses for both the authority education and students. He stated that training and staff development constitute an efficient method that the organization can use to renew its vitality continuously, and to make it more able to confront changes at the level of interior and exterior environment since it trusts the scientific and behavioral possibilities of its staff. He also confirmed that the increasing quality and quantity of national and international competition among organizations, and their race to provide the newest and best items and services in order to expand their market share have led to an increasing interest and management confirmation of the role training and development play to make the human resources at a high level of possibilities, skills and knowledge, in order to enable innovation, creativity and providing the newest and best products along with achieving a competitive advantage for the organization.

Several researchers defined training such as Durra (2003), who defined training as "The organized and planned effort to provide human resources of the organization with particular knowledge, to improve and develop their skills and possibilities, and to change their behavior and trends positively and constructively which might be reflected on the organization's performance improvement".

Also, Abu Tahoun ( 2000) defined it as "a learning process which includes the acquisition of skills, concepts and rules or the trends to increase and improve the individual's performance".

Nowadays, most countries seek for the achievement of compatibility between the graduates of educational institutions and the requirements of labor market. It appears that the application of co-operational education models, based on correlating education programs and training which are required by the labor market, is an efficient method for the achievement of such correlation. Therefore, educational institutions particularly those in tourism services are stirred by the need of modern business environment and designed and applied educational and training models prior to their students' actual work enrollment which become one of the most significant basic requirements for education's strategic planning. Thus, the Faculty of Tourism and Hospitality has set a practical course in the study plan in order to be an effective instrument to achieve the highest degrees of correlation between the graduates of different majors and the available jobs at the labor market.

Students of the Faculty of Tourism and Hospitality study many subjects in tourism and hospitality scope of work which require practical training. But, the practical application of acquired theoretical skills is still limited because most of their educational courses are divided into theoretical and practical hours which need the students to make a small project to fulfill the requirements for a particular material or through their graduation project. Undoubtedly, giving 
the students an opportunity to apply what they have theoretically learned in an actual work environment might achieve many benefits that are positively reflected on the students' professional future. Practical training will achieve a perfect benefit from the theoretical knowledge, and students will acquire practical skills and experiences. It also helps to bridge the gap between studying and work, and gives students an opportunity to refine their skills, to exchange experiences with others, and to recognize field culture and codes of conduct. For employment opportunities, there is no doubt that employers favor the students who have already gained training in the scope of work, as these students usually have more maturity, experience and confidence than the others who have not been given the opportunity to train.

The Faculty of Tourism and Hospitality realized the importance of practical training for students; such an experience has recently been activated, as students have been allowed to have practical training in their field in a company, an institution, or hotels which are suitable to their major. This training is considered as a requirement of students' own courses. This experience began a year and half ago, as a committee consisted of faculty members was formed to organize the steps of practical training and to direct the students during the training stages.

\section{Problem and Question of Study}

The Faculty of Tourism and Hospitality in the University of Jordan recently launched its practical training program for its students in cooperation with several local organizations offering services for tourists, such a program has not been evaluated to recognize its strengths, weaknesses, the problems it faces, and the opportunities to enhance it in the future have not been investigated. Therefore, this study was conducted to determine and recognize the efficiency of the practical course in the Faculty of Tourism and Hospitality, University of Jordan, from the perspective of the trainees.

Therefore, the study attempted to answer the following question:

1- To which extent is the practical course of Faculty of Tourism and Hospitality, University of Jordan, efficient from the perspective of the trainees?

\section{Methodology}

In this research, the Statistical Package for the Social Sciences (SPSS) was used for data entry as well as for examining the data later. Data preparation was the initial step, which aimed to convert raw data into a more structured format that is more appropriate for analysis. Tasks in this stage included data editing, data coding and data entry. Descriptive statistics were used to summarize respondent's characteristics, including demographic information, such as age, gender; also, questions about the participating company's profile, such as the numbers of Customer were included. Furthermore, inferential statistics were used to test hypotheses to determine the relationship between variables. In particular, Pearson Correlation was used to verify the association of interval level to the construct, whilst Chi-square was used to validate the association between nominal variables and the construct. 


\section{Macrothink

The survey form of the descriptive approach has been employed as it fits the nature and purposes of this study. The sample of the current study consists of (80) male and female students, (47) male students and (33) female students. They represent the sample of study which is taken from the population of 177 students of the Faculty of Tourism and HospitalityAqaba Branch; who were selected randomly from those students enrolled in the practical training courses in the first and second semesters of the academic year 2012/2013, and they constitute about (45\%) of the total students of the Faculty. In this study, the questionnaire is used as a method to collect primary data and information. The entire questionnaire divots have been conducted after looking over the educational literature, researches, and studies which are related to the topic of the current study, especially the scales and the questionnaire that have been used in the previous study (Al-Haliq, Taheeneh, and salameh, 2006). The questionnaire consisted of (34) items distributed to four divots: the divot of the possibilities, the divot of organization, the divot of supervision, and the divot of evaluation.

\subsection{Hypotheses}

1- There is an efficient supervision for the practical course of the Faculty of Tourism and Hospitality, University of Jordan, from the perspective of trainees.

2- There is an efficient evaluation for the practical course of the Faculty of Tourism and Hospitality, University of Jordan, from the perspective of trainees.

3- There are sufficient possibilities for the practical course of the Faculty of Tourism and Hospitality, University of Jordan, from the perspective of trainees.

4- There is an efficient organization for the practical course of the Faculty of Tourism and Hospitality, University of Jordan, from the perspective of trainees.

\subsection{Reliability of Instrument}

The reliability of the instrument has been tested by Cronbach's alpha coefficient test, and table (1) shows the following:

1. The value of alpha for the divot of supervision is 0.76

2.The value of alpha for the divot of evaluation is 0.81

3.The value of alpha for the divot of possibilities is 0.82

4.The value of alpha for the divot of organization is 0.70

5. The value of the entire paragraphs is 0.86 .

Thus, all these values are higher than 0.60, therefore, the instrument of study is reliable. 


\section{1) Macrothink}

Table1. Cronbach's Alpha test results and coefficient analysis test

\begin{tabular}{|l|l|l|l|l|l|}
\hline Divot & $\begin{array}{l}\text { Alpha } \\
\text { Value }\end{array}$ & $\begin{array}{l}\text { Saturation } \\
\text { (paragraphs } \\
\text { divots) }\end{array}$ & $\begin{array}{l}\text { Alpha } \\
\text { Value }\end{array}$ & $\begin{array}{l}\text { Saturation } \\
\text { (paragraphs } \\
\text { divots) }\end{array}$ \\
\hline Supervision & 0.76 & --- & possibilities & 0.82 & --- \\
\hline 1 & & 0.55 & 15 & & 0.95 \\
\hline 2 & & 0.61 & 16 & & 0.91 \\
\hline 3 & & 0.63 & 17 & & 0.69 \\
\hline 4 & & 0.61 & 18 & & 0.94 \\
\hline 5 & & 0.69 & 19 & & 0.63 \\
\hline 6 & & 0.74 & 20 & & 0.94 \\
\hline Evaluation & 0.81 & --- & 21 & & 0.55 \\
\hline 7 & & 0.42 & 22 & & 0.61 \\
\hline 8 & & 0.50 & organization & 0.70 & --- \\
\hline 9 & & 0.48 & 23 & & 0.61 \\
\hline 10 & & 0.49 & 24 & & 0.69 \\
\hline 11 & & 0.56 & 25 & & 0.81 \\
\hline 12 & & 0.57 & 26 & 0.94 \\
\hline 13 & & 0.51 & Total & 0.86 & -- \\
\hline 14 & & & & \\
\hline
\end{tabular}

\subsection{Method Validity}

The validity of the method has been verified by:

-showing it to a number of arbitrators in order to make sure that the items included in the method measure what is required, and belong to the right divot. In light of the arbitrators' notes, some paragraphs have been modified and other paragraphs have been deleted to reach a total of (27) paragraphs in order to become clearer in terms of their formulation and belonging to the divots they follow.

- using factor analysis to examine the extent to which paragraphs are related to the divot they belong to.

Table (1) shows the results of this analysis, since all the divergences of the paragraphs for each divot were higher than 0.30 and this is the criterion of acceptance; that is each paragraph is associated with the divot it belongs to. 
The first hypothesis:

From the perspective of the trainees, there is an efficient supervision for the practical training program at the Faculty of Tourism and Hospitality in the University of Jordan.

Table 2 indicates that all items, except item (4), have an average higher than 3.00 and have an observation significance level of less than 0.05 , which means that they are statistically acceptable.

Item (4), which measures the extent to which the supervisor keeps on attending continuously and periodically, occupies the first rank with an average of 4.40, on the other hand, item (1), which measures the extent to which the supervisor discusses the notes with the trainee after finishing the training, occupies the last rank among the statistically acceptable items.

Item (2), which measures the extent to which the supervisor presents the stimulation and the new ideas, has got an average of less than 3.00, which means that it is not a statistically significant.

For all items as a whole, the average is 3.72 (higher than 3.00) and the level of observation is 0.00 , thus there is a statistical significant to accept the first hypothesis, which means that there is an efficient supervision on the practical program at the Faculty of Tourism and Hospitality in the University of Jordan, from the perspective of the trainees.

Table 2. The Average, the Standard Deviation, and the Percentage of Supervision:

\begin{tabular}{|l|l|l|l|l|l|}
\hline No & Paragraph & Average & $\begin{array}{l}\text { Std } \\
\text { deviation }\end{array}$ & percentage & $\begin{array}{l}\text { P - } \\
\text { value }\end{array}$ \\
\hline 1 & $\begin{array}{l}\text { The supervisor discusses the notes with } \\
\text { the trainee after finishing the training }\end{array}$ & 3.49 & 1.17 & 5.93 & 0.00 \\
\hline 2 & $\begin{array}{l}\text { The supervisor always offers the } \\
\text { stimulation and the new ideas }\end{array}$ & 2.08 & 0.39 & -33.76 & 0.00 \\
\hline 3 & $\begin{array}{l}\text { The supervisor always offers the written } \\
\text { notes }\end{array}$ & 3.65 & 1.03 & 8.88 & 0.00 \\
\hline 4 & $\begin{array}{l}\text { The supervisor keeps on attending } \\
\text { continuously and periodically }\end{array}$ & 4.40 & 0.73 & 27.13 & 0.00 \\
\hline 5 & $\begin{array}{l}\text { The supervisor discusses the outlines of } \\
\text { the training program with the trainees at } \\
\text { the beginning of the practical training }\end{array}$ & 4.32 & 0.86 & 21.83 & 0.00 \\
\hline 6 & $\begin{array}{l}\text { The notes presented by the supervisor } \\
\text { help to improve the level of the trainees in } \\
\text { lessons }\end{array}$ & 4.38 & 0.83 & 23.51 & 0.00 \\
\hline Total & & & & & 0.00 \\
\hline
\end{tabular}


The second hypotheses:

From the perspective of the trainees, there is an efficient evaluation for the practical training program at the Faculty of Tourism and Hospitality in the University of Jordan.

Table (3) shows that all items have an average which is higher than 3.00 and have an observation significant which is less than 0.05 , which means that they are statistically acceptable.

Item (11), which measures the extent to which the supervisor uses the methods of progressive evaluation, occupies the first rank with an average of 4.02 .

Item (10), which measures the extent to which the supervisor uses suitable, various and modern evaluation methods, occupies the last rank.

For all items as a whole, the average is 3.76(higher than 3.00) and the level of observation significant is 0.00 , thus there is a statistical significant to accept the second hypothesis, which means that there is an efficient evaluation of the practical training program at the Faculty of Tourism and Hospitality in the University of Jordan, from the perspective of the trainees. 


\section{Macrothink}

Table 3. The Average, the Standard Deviation, and the Percentage of Evaluation:

\begin{tabular}{|c|c|c|c|c|c|}
\hline $\begin{array}{l}\text { Paragraph } \\
\text { number }\end{array}$ & Paragraph & Average & $\begin{array}{l}\text { Stander } \\
\text { deviation }\end{array}$ & percentage & $\begin{array}{l}\mathrm{P}- \\
\text { value }\end{array}$ \\
\hline 7 & $\begin{array}{l}\text { The supervisor sticks to the } \\
\text { instructions of the university } \\
\text { regarding the evaluation progress } \\
\text { for the trainees. }\end{array}$ & 3.95 & 0.94 & 14.20 & 0.00 \\
\hline 8 & $\begin{array}{l}\text { The administration of the faculty } \\
\text { shares the teacher of the practical } \\
\text { courses in putting a part of the } \\
\text { evaluation mark. }\end{array}$ & 3.88 & 1.16 & 10.67 & 0.00 \\
\hline 9 & $\begin{array}{l}\text { The supervisor makes sure that } \\
\text { the trainee will do the notes that } \\
\text { he writes them down in his } \\
\text { previous visit. }\end{array}$ & 3.73 & 1.09 & 9.42 & 0.00 \\
\hline 10 & $\begin{array}{l}\text { The supervisor uses suitable, } \\
\text { various and modern evaluation } \\
\text { methods. }\end{array}$ & 3.44 & 1.10 & 5.61 & 0.00 \\
\hline 11 & $\begin{array}{l}\text { The supervisor uses the methods } \\
\text { of progressive evaluation }\end{array}$ & 4.02 & 0.96 & 15.01 & 0.00 \\
\hline 12 & $\begin{array}{l}\text { The number of the supervisor's } \\
\text { visits is enough to evaluate the } \\
\text { trainee. }\end{array}$ & 3.49 & 1.19 & 5.74 & 0.00 \\
\hline 13 & $\begin{array}{l}\text { The supervisor's evaluation } \\
\text { method generates satisfaction } \\
\text { among trainees regarding the } \\
\text { objectivity of the evaluation. }\end{array}$ & 3.79 & 1.01 & 13.56 & 0.00 \\
\hline 14 & $\begin{array}{l}\text { The evaluation's method achieves } \\
\text { justice between students in the } \\
\text { evaluation. }\end{array}$ & 3.64 & 1.13 & 7.98 & 0.00 \\
\hline total & & 3.76 & 0.55 & 19.43 & 0.00 \\
\hline
\end{tabular}

The Third hypothesis:

From the Perspective of the trainees, there are enough possibilities for the practical training program at the Faculty of Tourism and Hospitality in the University of Jordan.

Table (4) shows that all paragraphs, except (19), (21), and (22), have an average which is higher than 3.00, and they also have an observation significant level which is less than 0.05 which means that they are statistically acceptable.

Item (17), which measures which measures the extent to which the faculty provides an emergency clinic for first aid and injury, occupies the first rank with an average of 4.00. On 
the other hand, item (20), which measures the extent to which the faculty makes servicing for the laboratories, the tools, and devices continuously and periodically, occupies the last rank among the statistically acceptable items.

Item (19), which measures the extent to which the faculty provides equipped laboratories for several practical applications with enough spaces that suit with the number of students, has an average which is less than 3.00 , which means that it is not statistically significant.

The average of Item (21), which measures the extent to which the faculty provides teaching methods and illustrations, is less than 3.00.This also, means that it is not statistically significant. In addition, item (22), which measures the extent to which the faculty provides adequate sanitation facilities and rooms for changing clothes during the training lesson, has got an average which is less than 3.00 so it is not statistically significant.

For all items as a whole, the average is 3.13(higher than 3.00) and the level of observation significant is 0.01 , thus there is a statistical significant to accept the third hypothesis, which means that there are enough possibilities for the practical training program at the Faculty of Tourism and Hospitality in the University of Jordan from the Perspective of the trainees.

Table 4. The Average, the Standard Deviation, and the Percentage of Possibilities:

\begin{tabular}{|c|c|c|c|c|c|}
\hline $\begin{array}{l}\text { Paragraph } \\
\text { number }\end{array}$ & Paragraph & average & $\begin{array}{l}\text { Standard } \\
\text { deviation }\end{array}$ & percentage & $\begin{array}{l}\mathrm{P} \text { - } \\
\text { value }\end{array}$ \\
\hline 15 & $\begin{array}{l}\text { The faculty provides a good } \\
\text { place for saving the required } \\
\text { tools, devices, and equipment. }\end{array}$ & 3.73 & 1.02 & 10.16 & 0.00 \\
\hline 16 & $\begin{array}{l}\text { The faculty provides an enough } \\
\text { number of the teachers and } \\
\text { supervisors of the practical } \\
\text { training. }\end{array}$ & 3.87 & 0.94 & 13.06 & 0.00 \\
\hline 17 & $\begin{array}{l}\text { The faculty provides an } \\
\text { emergency clinic for first aid } \\
\text { and injury. }\end{array}$ & 4.00 & 0.92 & 15.27 & 0.00 \\
\hline 18 & $\begin{array}{l}\text { The faculty provides the } \\
\text { required devices and equipment } \\
\text { that suit the number of the } \\
\text { students. }\end{array}$ & 3.94 & 1.01 & 13.22 & 0.00 \\
\hline 19 & $\begin{array}{l}\text { The faculty provides equipped } \\
\text { laboratories for several practical } \\
\text { applications with enough spaces } \\
\text { that suit with the number of } \\
\text { students. }\end{array}$ & 2.74 & 1.60 & -2.30 & 0.02 \\
\hline 20 & $\begin{array}{l}\text { The faculty maintains the } \\
\text { laboratories, the tools, and }\end{array}$ & 3.48 & 1.14 & 4.95 & 0.00 \\
\hline
\end{tabular}




\begin{tabular}{|l|l|l|l|l|l|}
\hline & $\begin{array}{l}\text { devices continuously and } \\
\text { periodically. }\end{array}$ & & & & \\
\hline 21 & $\begin{array}{l}\text { The faculty provides the } \\
\text { teaching methods and } \\
\text { illustrations (Video, Tourism } \\
\text { and hotel books, and tapes). }\end{array}$ & 2.06 & 0.32 & -34.94 & 0.00 \\
\hline 22 & $\begin{array}{l}\text { The faculty provides adequate } \\
\text { sanitation facilities and rooms } \\
\text { for changing clothes during the } \\
\text { training lesson. }\end{array}$ & 2.97 & 1.08 & -0.32 & 0.75 \\
\hline Total & & 3.13 & 0.43 & 2.82 & 0.01 \\
\hline
\end{tabular}

Fourth hypothesis:

From the Perspective of the trainees, there is an efficient organization for the practical training program at the Faculty of Tourism and Hospitality in the University of Jordan.

Table (5) shows that all items have an average which is higher than 3.00, and they also have an observation significant level which is less than 0.05 which means that they are statistically acceptable.

Item (24), which measures the extent to which the faculty chooses a qualified trainer for the practical training, occupies the first rank with an average of 4.22. On the other hand, item (23), which measures the extent to which the administration of the faculty helps the trainee in presenting and organizing the lecture of the practical training, comes at the last rank.

For all items as a whole, the average is 4.03(higher than 3.00) and the level of observation significant is 0.00 , thus there is a statistical significant to accept the forth hypothesis, which means that there is an efficient organization for the practical training program at the faculty of Tourism and Hospitality in the University of Jordan at from the Perspective of the trainees. 
Table 5. The Average, the Standard Deviation, and the Percentage of Organization

\begin{tabular}{|l|l|l|l|l|l|}
\hline $\begin{array}{l}\text { Item } \\
\text { number }\end{array}$ & Item & average & $\begin{array}{l}\text { Standard } \\
\text { deviation }\end{array}$ & percentage & $\begin{array}{l}\text { P - } \\
\text { value }\end{array}$ \\
\hline 23 & $\begin{array}{l}\text { The faculty helps in presenting and } \\
\text { organizing the lecture of the } \\
\text { practical training. }\end{array}$ & 3.69 & 0.98 & 8.65 & 0.00 \\
\hline 24 & $\begin{array}{l}\text { The faculty chooses a qualified } \\
\text { trainer for the practical training. }\end{array}$ & 4.22 & 0.75 & 20.18 & 0.00 \\
\hline 25 & $\begin{array}{l}\text { The faculty prepares students } \\
\text { theoretically and practically } \\
\text { according to the description of the } \\
\text { practical part in the course. }\end{array}$ & 4.14 & 0.86 & 16.29 & 0.00 \\
\hline 26 & $\begin{array}{l}\text { The administration of the faculty } \\
\text { previews the system used in its } \\
\text { practical program. }\end{array}$ & 4.20 & 0.86 & 17.18 & 0.00 \\
\hline 27 & $\begin{array}{l}\text { The faculty insists on using the } \\
\text { modern methods and modern ways } \\
\text { of teaching. }\end{array}$ & 3.91 & 0.92 & 11.97 & 0.00 \\
\hline total & & 4.03 & 0.52 & 24.68 & 0.00 \\
\hline
\end{tabular}

\section{Conclusion}

1. From the perspective of the trainees, there is an efficient supervision for the practical training program at the Faculty of Tourism and Hospitality in the University of Jordan as the supervisor discusses the notes with the trainee after finishing the training, offers the written notes permanently, keeps on attending continuously and periodically, and discusses the outlines of the training program with the trainees at the beginning of the practical training. Also, the notes presented by the supervisor help to improve the level of the trainees in lessons. On the other hand the supervisor doesn't always offer the stimulation and the new ideas.

2- From the Perspective of the trainees, there is an efficient evaluation for the practical program at the Faculty of Tourism and Hospitality in the University of Jordan as the supervisor sticks to the instructions of the university regarding the evaluation progress for the trainees, the administration of the faculty shares the teacher of the practical courses in putting a part of the evaluation mark.The supervisor makes sure that the trainee will do the notes that he writes them down in his previous visit, the supervisor uses suitable, various and modern evaluation methods, and he the uses the methods of progressive evaluation. In addition the number of his visits is enough to evaluate the trainee, and his evaluation method generates satisfaction among trainees regarding the objectivity of the evaluation and it achieves justice between students in the evaluation.

3- From the Perspective of the trainees, there are enough possibilities for the practical training program at the Faculty of Tourism and Hospitality in the University of Jordan. The 
faculty provides a good place for saving the required tools, devices, and equipment.It also provides an enough number of the teachers and supervisors of the practical training, an emergency clinic for first aid and injury, the required devices and equipment that suit the number of the students.In addition, the faculty makes servicing for the laboratories, the tools, and devices continuously and periodically. But the faculty doesn't provide equipped laboratories for several practical applications with enough spaces that suit with the number of students, and it doesn't provide the teaching methods and illustrations (Video, Tourism and hotel books, and tapes).

4- From the Perspective of the trainees, there is an efficient organization for the practical training program at the Faculty of Tourism and Hospitality in the University of Jordan as the faculty helps in presenting and organizing the lecture of the practical training, chooses a qualified trainer for the practical training, prepares students theoretically and practically according to the description of the practical part in the course.In addition, the administration of the faculty previews the system used in its practical program, and it emphasizes using the modern methods and modern ways of teaching.

\section{Recommendations}

1- The study recommends that the Faculty of Tourism and Hospitality in the University of Jordan insists on using the modern methods and ways for learning.

2- The study recommends that the Faculty of Tourism and Hospitality in the University of Jordan provides equipped laboratories for several practical applications with enough spaces that suit with the number of students.

3- The study recommends that the Faculty of Tourism and Hospitality in the University of Jordan provides the teaching methods and illustrations (Video, Tourism and hotel books, and tapes).

4- The Faculty of Tourism and Hospitality in the University of Jordan has to provide adequate sanitation facilities and rooms for changing clothes during the training lesson.

5- The Faculty of Tourism and Hospitality in the University of Jordan has to exert more effort to improve the training courses, and not to stop at the good level it has reached.

More studies should be conducted in order to know the efficiency of the courses in other faculties at other Jordanian universities.

\section{References}

Abdel- Rahman, Mazen,G. et. (2004). The impact of field training to improve the level of teaching competencies for students of the Faculty of Physical Education and Sports Science. Studies. Physical Education Conference: Sports model of contemporary life, a special issue. $142-150$.

Abu Namira, M. K. (2005). Evaluating practical educational program in the faculties of science education in private universities in Jordan from the perspective of teacher students. Mutah Journal for Research and Studies, 20(2),109 - 148. 
Abu Tahoun, A. A. (2000). Management and development of human and natural resources. Alexandria, modern office campus, p 51.

Al-Haliq, M. A., Taheeneh, Z. L., \& salameh, I. A. (2007). Evaluating the field-training program for physical education students at the Hashemite University. Mutah Journal for Research and Studies: Series Humanities and Social Sciences

Al-Salem,Moaid. (2007). Human Resource Management, El-Thraa for Publishing and Distribution, Amman, Jordan.

Ann Pollock, \& J.R.Brent Ritchie. (1990). Integrated strategy for tourism education/training,Annals of Tourism Research, 17(4), 568-585, http://dx.doi.org/10.1016/0160-7383(90)90028-P

Durra,A. B. (2003). Human performance technology in organizations: The theoretical foundations and implications in the modern Arab environment - Cairo, the Arab Organization for Administrative Development, p 103.

Fahmi, Atef. (2007). Developing the method of performance evaluation of vocational training for the students of the Faculty of Occupational kindergartens in light of the standard levels of performance using documentary files. Magazine of Reading and Knowledge, Cairo, Egypt.

Maria Yiua \& Rob Lawa. (2012). A Review of Hospitality Internship: Different Perspectives of Students, Employers, and Educators, Journal of Teaching in Travel \& Tourism, 12(4). http://dx.doi.org/10.1080/15313220.2012.729459

Melphon Mayaka, John S. Akama. (2007 ). Systems approach to tourism training and education: The Kenyan case study. Tourism management, 28(1), 298-306.

Messmar, Bassam, \& Khawaja, Ahmed (1996). Study students' attitudes towards the course of field application in colleges of Physical Education in Jordan. Studies, Proceedings of the Third Scientific Conference sports.

Michael Baker, Ann Cattet, \& Michael Riley. (1995). Practical food and beverage training in the UK: a study of facilities and a debate on its relevance. International Journal of Contemporary Hospitality Management, 7(5), 2124.

Talafha, M. A. (2003). Evaluating and developing field education program at Teachers College, Tabuk. Journal of teachers' colleges, 3(2), 117- 169.

Wood, K. (2000). The experience of learning to teach: changing student teachers ' ways of understanding teaching. Journal of Curriculum Studies, 31(1), 75-93. http://dx.doi.org/10.1080/002202700182862 